\title{
UN GRABADO GUADALUPANO
}

El infatigable y erudito historiador del arte español, doctor don José Crisanto López Jiménez, nos ha enviado desde su lejana y castiza Murcia, un curioso y hermoso grabado de la Virgen de Guadalupe de $M \dot{e}$ xico. El grabado perteneció a un coleccionista murciano, está finámente burilado en acero y lleva la siguiente firma abreviada: Bart. Vazquz. feuls. M., en el ángulo inferior derecho. El doctor López Jimónez atendiendo a la última letra, la $M$ supuso que el grabado era de origen mexicano, además así parecía indicarlo el tema del mismo.

La estampa es obra del grabador académico español, Bartolomé Vázquez (1749-1802), quien se especializó en láminas de carácter religioso y en Madrid tuvo taller propio, así lo indica con la $M$ que aparece en algunas de sus obras.

El grabado es de estilo académico y Bartolomé Vázquez débió copiar la imagen de la Virgen de Guadalupe, de alguna de las pinturas novoespañolas existentes en la península; por otra parte debió tener presentes los atributos propios de la venerada imagen, tales como el ayate o tilma de Juan Diego y las rosas de que habla la leyenda; ambas cosas las aprovechó con destreza para la composición de esta obra. La imagen de la Virgen lleva la corona que hoy en día no aparece en el lienzo original. Parte importante en la composición de la estampa, es el resplandor que encierra el símbolo del Espíritu Santo, la representación es típica en los artistas académicos.

Damos las gracias al doctor don José Crisanto López Jiménez, por el envio de esta lámina española que enriquece la iconografía guadalupana de México.

X. M. 


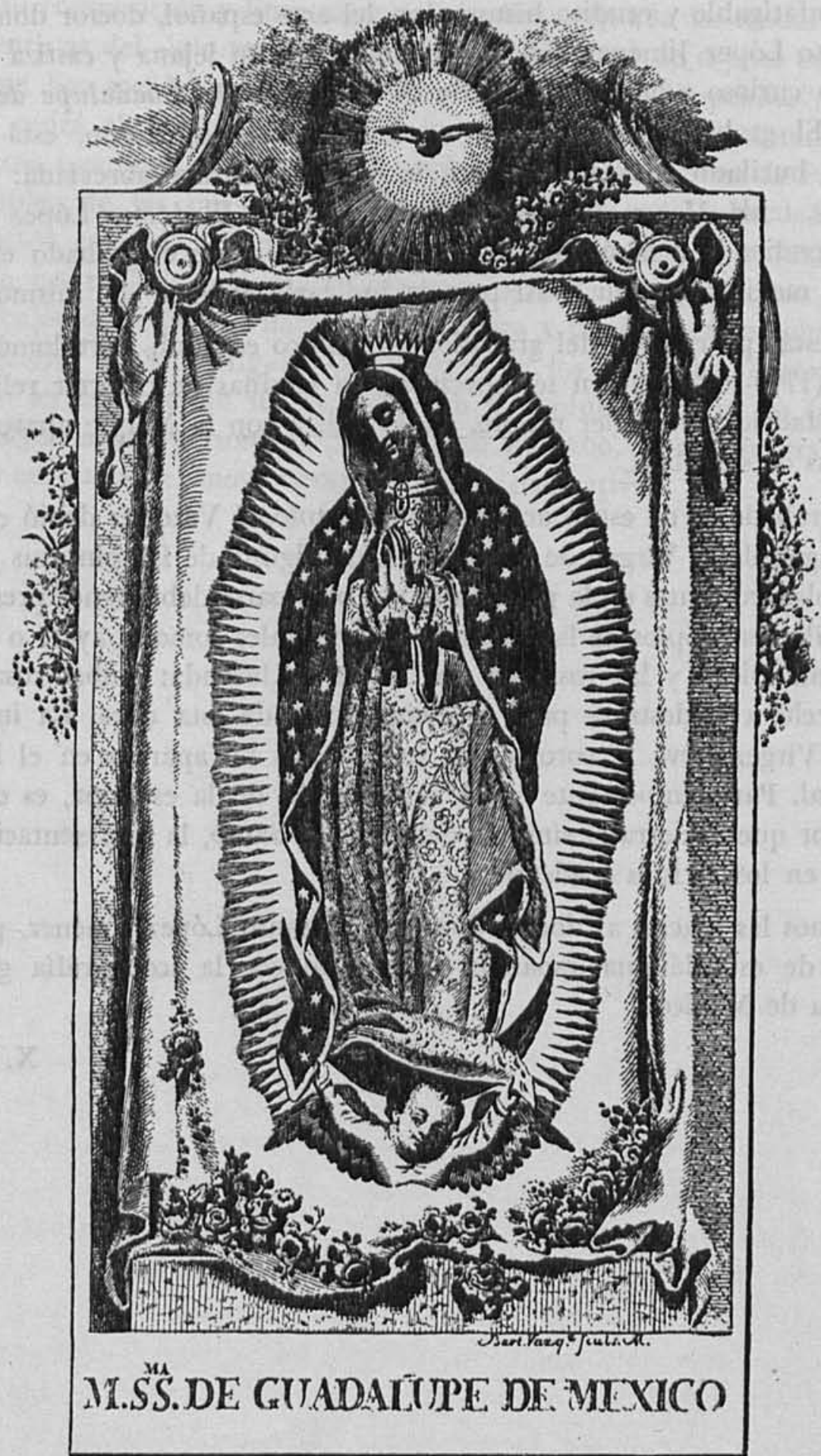




\section{NOMBRAMIENTO DEL DOCTOR JUSTINO FERNÁNDEZ COMO INVESTIGADOR EMÉRITO}

El H. Consejo Universitario en su sesión del 13 de octubre de 1969 tuvo a bien aprobar, por unanimidad, los dictámenes de las Comisiones del Trabajo Docente y del Mérito Universitario, para que sea nombrado Investigador Emérito el doctor Justino Fernández.

Cabe al Instituto de Investigaciones Estéticas el honor de que el doctor Justino Fernández, Director que fue del Instituto y su actual Consejero, haya sido nombrado Investigador Emérito, por sus méritos durante treinta y cuatro años de servicios en la Universidad Nacional Autónoma de México, y por contar con una amplia obra de investigación. 